Review

\title{
Environment, Development, and Ecologically Unequal Exchange
}

\author{
Andrew K. Jorgenson
}

Sociology Department, Boston College, Chestnut Hill, MA 02467-3807, USA; jorgenan@bc.edu; Tel.: +1-617-552-1293

Academic Editor: Marc A. Rosen

Received: 10 February 2016; Accepted: 26 February 2016; Published: 1 March 2016

\begin{abstract}
I begin this paper with summaries of environment and development perspectives foundational to contemporary environmental sociology: ecological modernization theory and treadmill of production theory. Descriptions of the perspectives are provided as well as an overview of recent quantitative cross-national analyses that evaluate the propositions of both theories. Next, I provide a summary of ecologically unequal exchange theory. I argue that ecologically unequal exchange theory helps to address key limitations of both the treadmill of production and ecological modernization approaches, most notably their lack of attention paid to how structural and unequal relationships between nations influence environment and development associations. Next, I summarize bodies of empirical work within sociology that employ quantitative measurements and statistical modelling techniques to test the propositions of ecologically unequal exchange theory. I conclude by emphasizing the need for greater integration between ecologically unequal exchange theory, the two environment and development perspectives, and other political economy traditions. I also briefly discuss fruitful avenues for future research.
\end{abstract}

Keywords: environment; development; ecologically unequal exchange; treadmill of production; ecological modernization; sustainability; environmental sociology

\section{Introduction}

The environmental impacts of economic development are among the central concerns of both development scholars and coupled human and natural systems researchers. Scientific investigations indicate that human activities are the primary force transforming ecosystems and climate conditions [1]. James Hansen, a leading U.S. climatologist, notes that the "planet is dangerously near a tipping point" given the accumulation of carbon dioxide in the atmosphere as well as the human footprint on the overall global ecological system. He points out that if we continue with business-as-usual, in terms of an expanding economy predicated on a resource-intensive and carbon-based energy system, cascading environmental problems will beset global society [2].

At the heart of much environment and development research and policy work is the assumption that the two are intimately interconnected in various forms, and human civilization faces the enormous task of identifying ways in which the ecological impacts of humans can be reduced while forms of economic and social development continue, especially in developing nations, with the assumption that development enhances the quality of life for populations. However, recent studies indicate that while economic development continues to be a key driver of human well-being in developing nations, the magnitude of development's effect on enhancing well-being has slightly decreased through time [3], while cross-national research by sustainability science scholars indicates that human well-being remains remarkably resource-intensive, especially in developed nations [4,5]. An additional conundrum well established by environmental justice and structural inequality scholars is that the societal benefits of 
development-whether they are environmentally intensive or not—do not benefit groups within or between societies equally.

While the speed and scale of the transformation of ecosystems in the modern era is unprecedented, the disparities in environmental damages are uneven within and especially between nations. Rich nations place more stress on the global environment, while poorer nations disproportionately contend with the effects and consequences of degraded and/or stressed ecosystems [6-8]. I suggest that international political economy perspectives have much to offer for theoretically-engaged research on environment and development research. And many other scholars have made similar arguments over the past few decades [9-13].

As important, well-established traditions within the environmental social sciences that focus on environment/development relationships, such as foundational theories in environmental sociology, would benefit from greater integration with international political economy perspectives that focus on such structural interrelationships between nations and regions [14-16]. Development doesn't happen in a vacuum, and development and underdevelopment are largely a function of the stratified global social system [17]. The stratified global social system shapes development and underdevelopment, which in turn contributes to various environmental and ecological problems at local, regional and global levels [18,19]. These two global systems, the human and the natural, are deeply interconnected, and the premise of these interconnections is at the heart of coupled human and natural systems scholarship [20,21].

In this review article I summarize environment and development perspectives foundational to contemporary environmental sociology: ecological modernization theory and treadmill of production theory. I provide descriptions of both perspectives as well as an overview of recent quantitative macro-analyses that evaluate the propositions of both perspectives. As will become clear, like most perspectives, these two have their strengths and limitations. Next, I provide an overview of the ecologically unequal exchange perspective. I argue that the ecologically unequal exchange perspective helps to address key limitations of both the treadmill of production and ecological modernization approaches, most notably their lack of attention paid to how structural relationships between nations influence environment and development associations. Besides describing the core arguments of ecologically unequal exchange theory, I summarize bodies of empirical work in sociology that employ certain forms of unique measurements and model estimation techniques to test the perspective's propositions. I end the article with some "take-home points" about the ways in which the discussed perspectives are related and the need for greater integration between them. I note how both treadmill-like and ecological modernization-like processes can and often do happen simultaneously, and how ecologically unequal exchange dynamics partially shape these simultaneous occurrences. I also briefly discuss fruitful avenues for future research.

\section{Environment and Economic Development}

\subsection{Ecological Modernization Theory}

Ecological modernization theory attempts to explain "how various institutions and social actors attempt to integrate environmental concerns into their everyday functioning, development, and relationships with others, including their relation with the natural world" [22]. The theory builds upon a longstanding approach in environmental economics which recognizes that development contributes to environmental harms, but argues that further economic development can lead to a reduction in such problems [23]. The environment is perceived as a luxury good, subject to public demand through the workings of an advanced market. During earlier stages or periods of economic development, environmental harms increase, but as development and affluence reach a certain point, the value the public places on the natural environment increases. The shared interest in quality of life enhancement-partly expressed as consumer demand for "sustainable" services and products-will, environmental economists argue, lead to added pressure on governments and the private sector to 
invest in "eco-friendly" production systems and other technologies. These added pressures should lead to increased availability of sustainable commodities and services. More broadly, it is argued that if market interference is minimal, economic growth will eventually lead to a leveling off and eventual decline in the use of natural resources and emission of waste. The proposed trend, known as the environmental Kuznets curve, is depicted as an inverted U-shaped distribution representing the relationship between environmental impacts and economic development.

The sociological theory of ecological modernization argues that the only "possible way out of the ecological crisis is by going further into the process of modernization" [24]. The forces of modernization that are capable of moving human society from its past of environmental degradation towards sustainability are the institutions of modernity, which include markets, technology, industrialism, and the state $[25,26]$. An "ecological rationality" will emerge and infiltrate the different parts of society, as environmental concerns are integrated into decision-making, and ecological costs are weighed along with economic considerations [27].

It is argued that during the earlier stages of modernization, a type "economic rationality" is commonly employed as the basis to evaluate development as well as broader social processes and relationships. Under these conditions, economic growth is the measuring stick of progress, while environmental harms and social ills are seen as minor consequences. Early stages of economic development have heightened environmental impacts. However, late modernity holds the potential for critical assessments and reflexivity, partly facilitated by the scientific community, social movements, business leaders, and government officials. An "ecological rationality" emerges and flows throughout society, as sustainability concerns are better aligned with self-interests, which influence relationships between society and the environment [24,27]. In a similar vein, Ronald Inglehart's "postmaterialist values" thesis posits that in the past, societies and individuals had to remain focused on survival, or material concerns; however, with the rise of the welfare state and the economic growth of advanced industrial and postindustrial societies, survival needs no longer have to be a top priority, giving rise to postmaterialist values including freedom of choice and the improvement of environmental conditions [28-30].

The forces of modernization will enhance environmental sustainability with the simultaneous "ecologization of economy" and the "economization of ecology" [27]. These transformations should lead to the dematerialization of society and a relative decoupling of the economy from environmental inputs and waste [24]. The economy becomes progressively eco-efficient in its resource use, and as a result, economic growth becomes less dependent upon and decoupled from nature. Thus, the dematerialization of the economy-through efficiency gains and technological innovations-decreases the demands that nations and their populations place on nature [31].

Through the ecologization of the economy, it is possible that the environmental impacts of nations will gradually decrease. While it is more likely for such a relative decoupling between economic development and environmental harms to take place first for the most economically developed nations, as other lesser-developed nations continue to develop, the magnitude of their environmental impacts should also eventually decline as well. In other words, while the economy might continue to harm the environment, ecological modernization theory suggests that through time the relative magnitude of the impact of economic development on the environment will decrease, and it is likely that these changes will happen first in the more economically developed nations [27].

\subsection{Treadmill of Production Theory}

Treadmill of production theory argues that environmental degradation is a direct consequence of economic development [32,33]. Since the economy is predicated on never-ending expansion and the pursuit of profit, economic functioning has "direct implications for natural resource extraction", the generation of pollution, and the overall state of ecological systems [34]. The economy generates environmental problems since it continually withdraws natural resources to produce commodities and fuel machinery, and such activities also generate waste. Technological developments expand and 
intensify production, so the volume of energy consumed and materials used increases. The state, while often caught in contradictory positions, is an important institution that supports economic expansion through bailing out industry and finance, negotiating trade agreements, protecting private property, and promoting military spending.

Allan Schnaiberg, the founder of treadmill of production theory, argues that all societies driven by economic expansion are mired in a conflict with nature [32]. Such societies are running endlessly, expending resources and consuming energy at an accelerating pace [33]. "The 'treadmill' component recognizes that the nature of capital investment leads to higher and higher levels of demand for natural resources ... . For ecosystems, each level of resource extraction becomes commodified into new profits and new investments, which leads to still more rapid increases in demand for ecosystem elements" [34]. Nature is used to fuel industry and commodity production, and the production process emits an increasing volume of environmentally harmful waste [35].

The treadmill of production perspective recognizes that technological innovation often involves improving the efficiency of operations, where fewer inputs are used to produce a specified amount of output. But whether efficiency leads to an overall reduction in resource demands-a decoupling of the economy and environment -is strongly questioned. According to the Jevons Paradox [36,37], it is possible for an economy to become more efficient in resource use, while at the same time expanding its consumption of resources. The treadmill of production perspective suggests that this situation manifests itself because gains made in improving efficiency are outstripped by increases in the scale of production.

More broadly, the treadmill of production perspective suggests that the association between environmental harms and economic development has remained fairly constant or possibly increased in magnitude through time. The drive for continual growth through expanded production necessitates a constant withdrawal of natural resources at rates that generally exceed the regenerative capacity of ecosystems [38]. Modern industries pursue economic efficiencies to enhance production processes and to increase profits. Energy-intensive materials are routinely incorporated into manufacturing, generating a growing range of waste [33,39]. Producers attempt to externalize environmental costs as much as possible to enhance profits.

Like ecological modernization theory, treadmill of production theory emphasizes that human civilization is dependent upon the biophysical world, but the latter is skeptical of the notion that the relationship between economic development and environmental degradation should decrease in magnitude through time, regardless of a society's level of development. Rather, treadmill of production theory argues that the constant drive to expand capital increases the volume of natural resources and energy that are extracted and used to sustain the productive operations on a larger and more intensive scale [34].

\subsection{Some Empirical Evidence}

A sizable body of comparative-international research in sociology attempts to evaluate the competing propositions of ecological modernization theory and treadmill of production theory [15,40-44]. In recent years, with the availability of cross-national panel data for various ecological and environmental outcomes, most notably anthropogenic carbon emissions and the ecological footprints of nations, Jorgenson and colleagues $[6,16,45,46]$ have employed statistical modeling techniques to analyze the panel data, and have focused on assessing the extent to which a relative decoupling between the environment and economic development has taken place. Such analyses allow for testing the contrasting propositions of ecological modernization theory and treadmill of production theory (see also [47]). Here I provide two examples of this body of work.

Figure 1 reports the estimated coefficients derived from Jorgenson and Clark's [6] two-way fixed effects panel models for the effect of gross domestic product per capita on the per capita ecological footprint for a sample of 18 developed nations and a sample of 47 less-developed nations. The estimated coefficients are provided for the years 1960 to 2000 in five year increments as well as 
for the year 2003. The line with squares is for the sample of developed countries and the line with triangles is for the sample of less-developed countries. The models include a number of important political-economic and human-ecological statistical controls, all explained in greater detail in Jorgenson and Clark [6]. The figure suggests that for both samples, the relationship between the ecological footprints of nations and economic development became stronger through time for both samples (i.e., an increasing effect of GDP per capita), which suggests the opposite of decoupling in a relative or an absolute sense. As important, the estimated effects are quite similar for the two samples, suggesting similar structural relationships between development and overall consumption based environmental demand. Generally speaking, these results correspond with the propositions of treadmill of production theory and thus conflict with the arguments of ecological modernization theory.

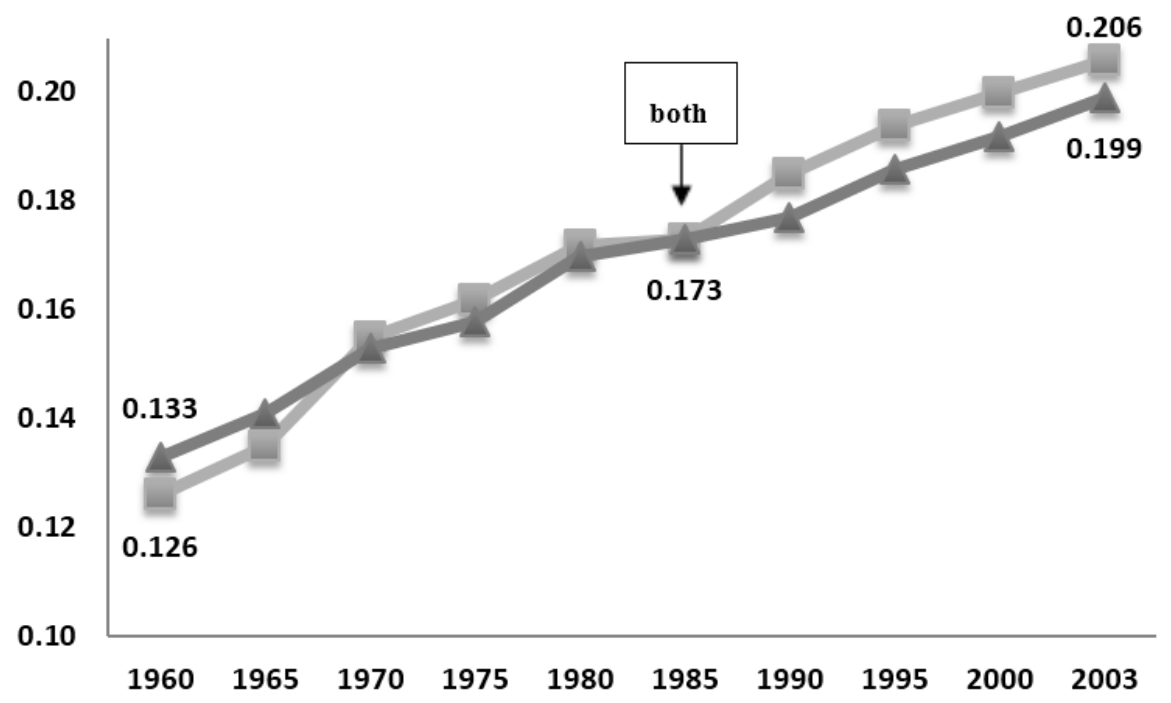

Figure 1. Estimated coefficients for the effect of GDP per capita on the per capita ecological footprint for a sample of developed countries and a sample of less-developed countries.

Figure 2 presents the estimated coefficients for the effect of GDP per capita on per capita carbon emissions for a sample of 22 developed countries and a sample of 64 less-developed countries. These analyses come from Jorgenson and Clark's [16] study of the relationship between economic development and carbon emissions, and like the analysis reported in Figure 1 above, the coefficients here are also derived from two-way fixed effects panel regression models and include various statistical controls. The time coverage in this study is 1960 to 2005, and the data are point estimates for five year intervals (i.e., 1960, 1965,..., 2000, 2005). The line with squares is for the sample of developed countries and the line with triangles is for the sample of less-developed countries. The results indicate that in developed countries the effect of economic development on carbon emissions is much larger than in less-developed countries and it remains quite stable in size through time, at least from 1960 to 2005. For the sample of less-developed countries, while the effect of economic development on carbon emissions is much smaller in value throughout the entire 45-year period than in developed countries, the relationship between emissions and development for these nations become somewhat stronger during the period of investigation. These results also provide support for treadmill of production theory. There is no evidence of decoupling in developed countries or less-developed countries, and in the latter the opposite is found: an intensification of the relationship between carbon emissions and economic development. 


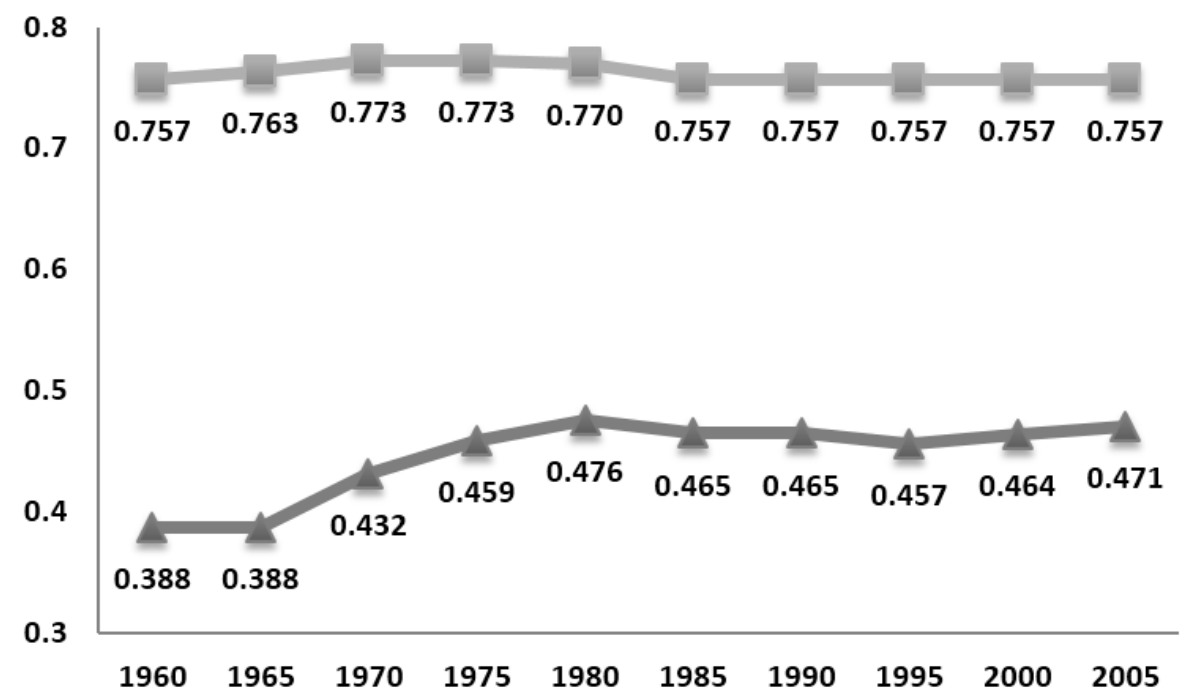

Figure 2. Estimated coefficients for the effect of GDP per capita on per capita carbon emissions for a sample of developed countries and a sample of less-developed countries.

Overall, the empirical evidence from the cross-national research in sociology tends to support the propositions of treadmill of production theory (see also [43]). However, as noted by Jorgenson and Clark [16], both ecological modernization theory and treadmill of production theory include shortcomings as far as addressing the structural relationships between environmental harms and economic development. They suggest that both orientations would greatly benefit from incorporating arguments and evidence from other bodies of macrosociological inquiry that focus explicitly on shifts in the transnational organization of production and the structure of international trade within the world economy, including the ecologically unequal exchange perspective. I now turn to a discussion of ecologically unequal exchange theory and related bodies of empirical work.

\section{Ecologically Unequal Exchange}

The unequally structured ecological relations between countries is articulated by the theory of ecologically unequal exchange, a perspective that describes the unequal material exchange relations and consequent ecological interdependencies within the world economy, all of which are fundamentally tied to wide disparities in socio-economic development and power embedded within the global system $[6-8,12,15,48-50]$. For purposes of this discussion, unequal exchange is broadly defined as the assertion of asymmetrical power relationships between more-developed and less-developed countries, wherein the former gain disproportionate advantages at the expense of the latter through patterns of trade as well as other structural relationships.

Ecologically unequal exchange refers to the environmentally damaging withdrawal of energy and other natural resource assets from and the externalization of environmentally damaging production and disposal activities within less-developed countries. It constitutes the obtainment of natural capital (stocks of natural resources that yield important goods and services) and the usurpation of sink-capacity (waste assimilation properties of ecological systems in a manner enlarging the domestic carrying capacity of more powerful developed countries) to the detriment of developing countries. It is focused upon the manner and degree to which less-developed countries tend to fulfil a role in the world economy as a tap for the raw materials and sink for the waste products of industrialized countries, thereby underwriting the disproportionate production-consumption-accumulation processes of more-developed countries [51].

Bunker [9,52] and Bunker and Ciccantell [53] have crafted a body of comparative-historical research that is particularly responsive to the ecologically unequal connections forged through world-economic processes. They illustrate the crucial role that reliable access to cheap natural resources 
has played in fueling the rise of hegemonic or global powers within a given historical era. From their perspective, orthodox theories of development have insufficiently recognized the fundamental differences between the internal dynamics and logic of accumulation of extractive and productive economies, respectively. It is not extraction of natural resources and energy, per se, that promotes ecologically unequal exchange, but the socio-organizational consequences this tends to produce between and within exporting and importing nations. The historical interactions between modes of extraction and production create path-dependent dynamics shaping the development trajectories of differentially situated countries.

Ecologically unequal exchange, therefore, is contingent upon differential cross-national social organization and accelerated production-consumption-accumulation linkages in the industrialized countries-facilitating the ability of state and private capital interests to determine global demand for natural resources [52,54]. Their capacity to control demand ensures that core interests engage in the substantive decisions regarding global export activity, and subjects less-developed countries to ever-changing market demands [53]. Local populations, social organization, infrastructure and ecosystems within peripheral extractive regions are often disrupted in the face of the malleable needs of developed countries. Extractive regions failing to conform to core interests are likely to be subject to declining terms of trade or abandoned entirely in lieu of other, more accommodating locations. Differential cross-national social power, in turn, is based upon historically contingent exchange relationships forged through the ability to control asymmetrical flows of environmental resources and risks [55,56].

These forms of transnational and international processes are also part and parcel of what McMichael [57] refers to as the "globalization project". Pointing to a shift that began in the late 1970s and early 1980s, his analysis focuses on export-oriented production and the attraction of foreign direct investment as two related means that less-developed nations attempt to employ to stimulate economic development. Through formal and informal mechanisms, global institutions such as the World Bank and International Monetary Fund increasingly encourage such activities, which they promote as critically important for less-developed countries to establish positions in the increasingly integrated world economy. In turn, the wealthier nations, by increasing consumption of manufactured products, agricultural goods and extracted materials, exacerbate environmental harms within developing countries. These constitute some of the key mechanisms underlying the ecologically unequal exchanges between developed and less-developed countries.

Over the past decade or so, a number of sociologists have attempted to develop and employ appropriate quantitative measures in comparative international studies to test propositions derived from ecologically unequal exchange theory. Early on, Jorgenson [58] designed a measure-referred to as "weighted export flows"-that quantifies the relative extent to which a nation's exports are sent to more-developed countries. This weighted index, which involves the use of relational data (export flows between sending and receiving nations) and attributional data (levels of development of receiving nations), includes all primary sector and secondary sector exports. These data were used initially in a study of deforestation from 1990 to 2000, which concluded that the vertical flow of all exports contributes to forest degradation in less-developed countries, net of demographic and political-economic factors, including levels of exports and classic trade dependence measures [49]. This initial weighted index is employed in earlier cross-sectional studies of the ecological footprints of nations [50] and industrial organic water pollution levels in developing nations [59]. The results of both studies are consistent with the propositions of ecologically unequal exchange theory. However, these initial studies are limited in particular ways. For example, Jorgenson's [49] deforestation analysis lacks temporal depth, and the use of a measure for all exports is problematic since research on forest degradation often emphasizes the relevance of trade in primary sector goods [60].

In part to address weaknesses in prior empirical work, Jorgenson, Dick and Austin [61] employ a weighted flows measure for only primary sector goods in analyses of deforestation in less-developed countries from 1990-2005. Findings reveal a strong association between forest degradation and 
the vertical flow of primary sector exports (see also [62,63]). Likewise, Shandra et al. [64] employ a weighted exports flow measure for primary sector commodities in a cross-sectional analysis of threatened mammals in less-developed countries. Consistent with the theory of ecologically unequal exchange, the results of their negative binomial regression model estimates indicate that numbers of threatened mammals in poor nations are positively associated with flows of primary sector exports to rich nations.

To help resolve the temporal limitations of prior cross-sectional studies, Jorgenson [65] employs panel analysis techniques in a study of the vertical flow of exports and the per capita ecological footprints of less-developed countries from 1975 to 2000. Results confirm a negative association between the overall consumption-based environmental demands per person in developing countries and the flow of total exports from those countries to relatively more-developed nations. The association increased in magnitude over the entire 25-year period, suggesting that these relationships became more ecologically unequal through time.

Jorgenson, Austin and Dick [66] take a similar approach, employing a weighted export flows measure for only primary sector commodities in panel analyses of deforestation and a refined, primary sector ecological footprint—known as the cropland, grazing land, and timber footprint (e.g., "CGT footprint") — for a sample of less-developed countries from 1970 to 2000. Like the preceding studies, their export flows measure is weighted by the levels of economic development of receiving countries. Jorgenson et al. [66] estimate fixed effects and random effects longitudinal models for both outcomes, allowing for more rigorous hypothesis testing. Consistent with prior research and the propositions of ecologically unequal exchange theory, they find that increases in the vertical flow of primary sector exports contribute to increases in forest degradation and concomitant suppression of the CGT footprint. The results hold, net of various controls and across both types of panel model estimations. Figure 3 reports the standardized regression coefficients (for the predictors with statistically significant effects) from Jorgenson et al.'s [66] fixed effects panel analysis of deforestation. Consistent with the vast body of work on deforestation, economic development and population growth have notable impacts on deforestation in less-developed countries. However, the relative magnitude of the effect of primary sector weighted export flows is greater than all other predictors included in the analyses, including relative levels of primary sector exports (i.e., primary exports as \% GDP).



Figure 3. Standardized regression coefficients from panel analysis of deforestation in less-developed countries, 1970 to 2000 .

In one of the most thorough cross-national analyses in the ecologically unequal exchange tradition to date, Jorgenson and Clark [15] integrate the tradition with two contemporary theories in 
environmental sociology: the treadmill of production and the treadmill of destruction, respectively. Treadmill of production theory, which is addressed in greater length in preceding sections of this article, focuses on how an economic system driven by endless growth, on an ever larger scale, generates widespread ecological degradation [35]. Treadmill of destruction theory suggests that the military has its own expansionary dynamics, which involve significant environmental and ecological costs $[67,68]$. Jorgenson and Clark [15] argue that the ecologically unequal exchange perspective intersects with both treadmill orientations. The treadmill of production propels the world economy toward constant expansion, demanding more and more resources to meet its insatiable appetite especially in the articulated consumer markets of developed countries. Similarly, in the interests of national security, technological innovation, political power and geopolitical influence, the treadmill of destruction facilitates the increased consumption of resources by the nations' militaries and their supporting sectors. As suggested by political sociologists, increased military strength enhances access to the natural resources and sink capacity of less-powerful, underdeveloped nations [17,69], and other environmental sociologists have recently highlighted the role of militarism and armed violence in international environmental inequalities in both contemporary and historical contexts [70,71].

Jorgenson and Clark [15] argue that the populations of more-developed and militarily powerful countries are positioned advantageously in the contemporary world economy, and thus more likely to secure and maintain favorable terms of trade allowing for greater access to the natural resources and sink capacity of bioproductive areas within less-developed countries. These advantageous positions facilitate the externalization of environmental costs of resource extraction and consumption to less-developed countries, and help create conditions where more-developed countries and those with more powerful militaries are able to over-utilize global environmental space. The misappropriation of global environmental space suppresses resource consumption opportunities for the populations of many less-developed countries.

To test their arguments and to assess the extent to which these perspectives intersect in meaningful and empirically valid ways, Jorgenson and Clark [15] create and employ two export flows measures. One is weighted by the levels of economic development of receiving countries, the other by military expenditures per soldier of receiving countries. Military expenditures per soldier is an established measure of military power in various bodies of sociological research [72,73]. The two export flows measures are treated as predictors in panel analyses of the ecological footprints of nations from 1975 to 2000. Most notably, the results of their panel model estimates indicate that countries with relatively higher levels of exports sent to economically developed and militarily powerful nations experience suppressed consumption levels, and these effects—-that are independent of one another-are especially pronounced and increasingly so for less-developed countries, many of which consume resources well below globally sustainable thresholds. In other words, both forms of structural relationships between nations have become increasingly unequal in ecological contexts.

All of the research discussed so far in this section of the article focuses on how the structure of international trade in ecologically unequal contexts contributes to increases in environmental degradation in less-developed countries as well as the suppression of resource consumption for domestic populations in developing nations, often well below globally sustainable limits. The latter also contributes to the well-being of these populations, which underscores the complexity of resource use and human health associations [74]. At the same time, it is argued that ecologically unequal exchange relationships between nations are likely to contribute to an increase in the production and dumping of various forms of environmental waste in less-developed countries. Such waste is the result of the off-shoring of environmentally-intensive manufacturing and the externalizing of the post-consumption disposal costs associated with manufactured goods for the articulated markets in more-developed countries. The focus here is on the international treatment of less-developed countries as sinks for waste. While such unequal structural relationships and consequences are central to the theory of ecologically unequal exchange, comparative international research on these topics is limited. 
Notable exceptions in sociology include Roberts and Parks [8] and Jorgenson [75,76], all of which focus on how ecologically unequal relationships contribute to anthropogenic carbon dioxide emissions.

Roberts and Parks [8] estimate cross-sectional models of total emissions, per capita emissions, emissions per unit of production, and cumulative emissions per capita for a large sample of nations. The first three outcomes are measured in 1999, while the fourth measure is a cumulative score for the 1950 to 1999 period. Net of multiple controls, they find that nations with a greater reliance on the export of manufactured goods have higher levels of all four types of emissions. Even though Roberts and Parks [8] do not include relational measures of trade, their results are generally consistent with the arguments of ecologically unequal exchange theory, and they make such a claim in their study.

Jorgenson [76] conducts a longitudinal analysis of per capita carbon dioxide emissions for a large sample of developed and less-developed nations for the 1960 to 2005 period. Due to data availability challenges, he employs a measure obtained from the World Bank that measures the percent of nations' exports sent to high income nations. This measure is correlated with the weighted export flow measure above a value of .9. Others have also employed the World Bank measure [7] to evaluate the propositions of ecologically unequal exchange theory. Jorgenson [76] finds that the effect of a country's proportion of exports to high income nations on per capita emissions is positive and much larger in magnitude for less-developed countries than for developed countries. Furthermore, and of particular note, in models for a sample restricted to only less-developed countries, he finds that the size of the effect of the vertical flow of exports on per capita emissions increases through time, providing evidence of increasingly ecologically unequal relationships between developed countries and less-developed countries. Figure 4 reports Jorgenson's [76] estimated coefficients for the effects of proportion of exports to high income nations on per capita carbon emissions in less-developed countries. With values of .011 in 1960 and .105 in 2005, the effect of the vertical flow of exports in this context on per capita emissions increased by approximately 950 percent from 1960 to 2005.

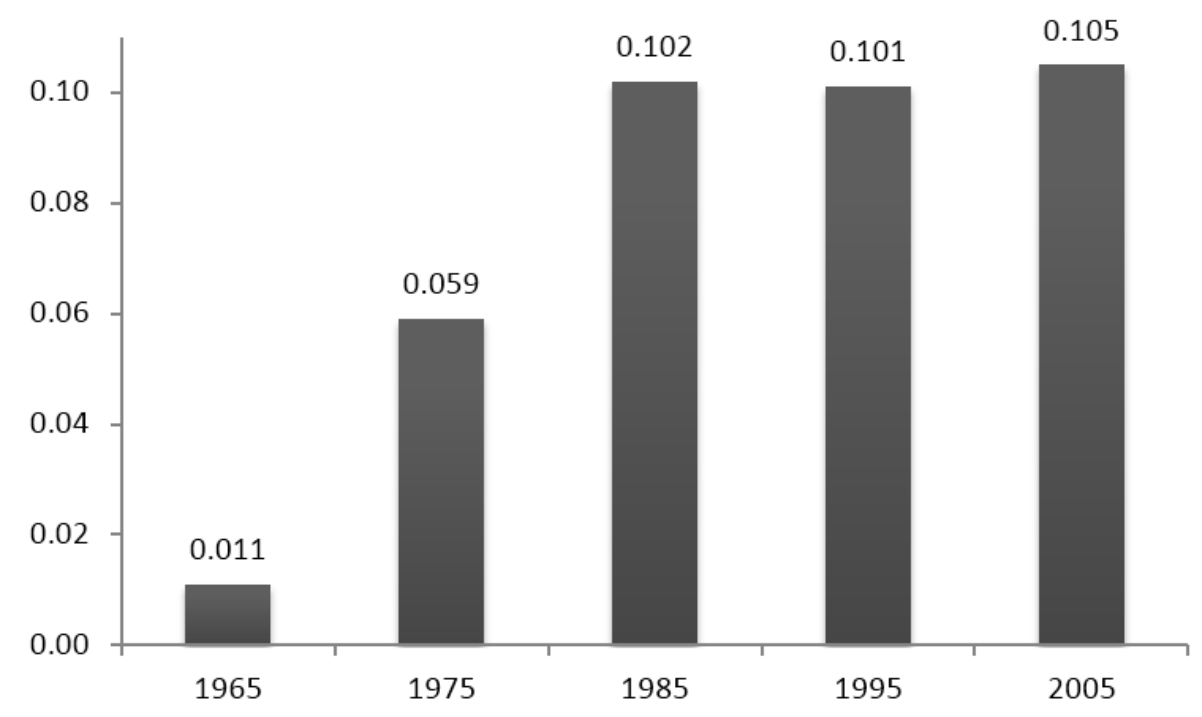

Figure 4. The estimated effect of proportion of exports to high income nations on per capita carbon emissions in less-developed countries.

In a related study, Jorgenson [75] employs the same key independent variable (percent exports to high income nations) and dependent variable (per capita carbon emissions) in two-way fixed effects panel analyses, but instead focuses on the transition economy nations of Central and Eastern Europe (CEE) from 1992 to 2005. For the thirteen CEE nations included in the study, the mean percent of exports to high income nations increased from slightly above 42 percent in 1992 to approximately 60 percent in 2005, while their actual levels of exports (i.e., exports as \% GDP) did not grow nearly as much during this period. Such shifts are of particular relevance from an ecologically unequal exchange 
perspective, since the commonly tested propositions of the theory focus on the environmental impacts of the vertical flow of exports to high income, developed nations. Figure 5 reports the estimated effects of percent exports to high income nations on carbon emissions for key years from Jorgenson's [75] study. Overall, it appears that the vertical flow of exports went from being environmentally beneficial to quickly becoming environmental harmful in the form of growth in carbon emissions. In other words, the structure of international trade rapidly transitioned from ecologically beneficial for CEE nations to ecologically unequal.

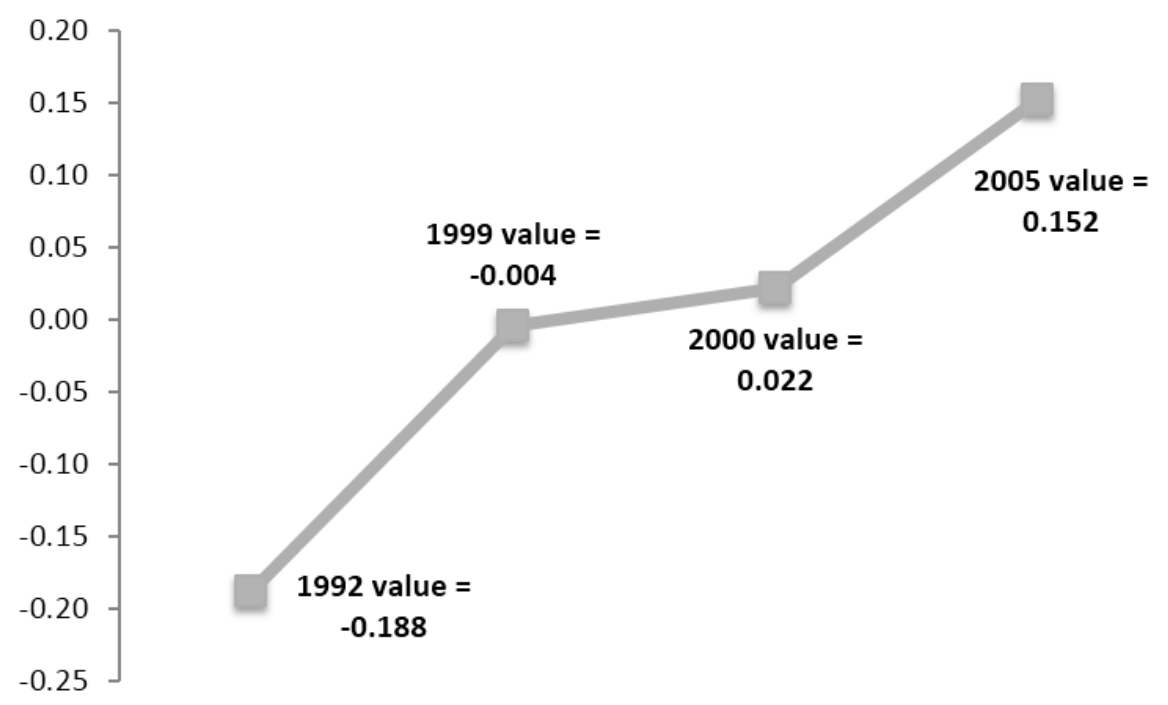

Figure 5. The estimated effect of percent exports to high income nations on per capita carbon emissions in CEE Nations.

\section{Conclusions}

Environment and development relationships are complex, and have remained at the heart of theoretical debates and empirical research in environmental sociology, its sister disciplines, and the broader coupled human and natural systems scholarly community. As highlighted in this review article, ecological modernization theory and treadmill of production theory both provide rich sociological frameworks for understanding the dynamic underpinnings of economic development's environmental impacts. Cross-national research that employs quantitative methods tends to support the propositions of treadmill of production theory and thus question the validity of ecological modernization's propositions. However, it is important to recognize that ecological modernization dynamics do take place on smaller scales and much in-depth qualitative research on specific firms and facilities provide examples of how stabilizations and perhaps relative (or even absolute) reductions in environmental impacts can occur through ongoing developmental and modernization processes, such as technology upgrades and changes in transportation practices of firms and their subsidiaries. But these micro-occurrences of ecological modernization are embedded in broader treadmill-like conditions where the overall scale and intensification of development and production outstrip the observable ecological benefits of the facility-level ecological modernization success stories [77]. This is far beyond an analytical issue. The more powerful treadmill forces are destroying the earth's regional and global ecosystems and contributing to climate change. At the same time, underdevelopment enhances the vulnerability of less-developed nations to these ecological catastrophes.

More broadly, both treadmill of production theory and ecological modernization theory are limited in their abilities to explain how environment and development relationships in one nation are partly structured by broader world-economic dynamics concerning trade networks, global production systems, and other sorts of horizontal and vertical transnational linkages. Such limitations are emphasized in recent studies in macrosociology $[6,15,16,44,78]$. Ecologically unequal 
exchange is an emergent perspective that helps explain the differing trends and trajectories in environment/development relationships occurring in developed and developing nations. While this perspective has gained notable momentum in recent years one must recognize that other scholars in decades past, such as Stephen Bunker [9] and Peter Grimes [11] were quite explicit in arguing that environment and development/underdevelopment conditions in different regions of the world are a function of (ecologically) unequal relationships and broader international inequality dynamics. Without doubt, these earlier works planted the seed for ecologically unequal exchange scholarship to emerge and flourish.

Future sociological work on environment and development would benefit from stronger integrations of ecological unequal exchange and other related approaches with treadmill of production theory and ecological modernization theory. As important, future integrative work needs to move beyond zero-sum sorts of characterizations of these various perspectives and conduct rich environment and development comparative analyses at multiple scales that employ a plurality of methods. Past data availability issues have limited the possibilities for such studies, but data have become increasingly available at facility-, city-, state-, regional-, and national-levels, and recent advances in methods and modeling techniques will allow for researchers to emerge these data of nested units into larger, more comprehensive studies $[79,80]$. As the saying goes, there is still much work to be done!

A prior version of this article was presented at the conference titled "Development and Underdevelopment in the Modern World-System: From Empirical Work to Reconceptualization", hosted by the Fernand Braudel Center for the Study of Economies, Historical Systems, and Civilizations at Binghamton University, 19-20 October 2012. The author thanks Denis O'hearn and Richard Lee for the invitation to speak at the conference on these topics, and he also thanks the conference attendees for their thoughtful suggestions and questions.

Conflicts of Interest: The author declares no conflicts of interest.

\section{References}

1. United States (U.S.) National Research Council. Advancing the Science of Climate Change; National Academies Press: Washington, DC, USA, 2010.

2. Hansen, J. Tipping Point. In State of the World 2008; Fearn, E., Redford, K.H., Eds.; Island Press: Washington, DC, USA, 2008.

3. Brady, D.; Kaya, Y.; Beckfield, J. Reassessing the Effect of Economic Growth on Well-Being in Less-Developed Countries, 1980-2003. Stud. Comp. Int. Dev. 2007, 42, 1-35. [CrossRef]

4. Dietz, T.; Rosa, E.; York, R. Environmentally Efficient Well-Being: Is there a Kuznets Curve? Appl. Geogr. 2012, 32, 21-28. [CrossRef]

5. Jorgenson, A.; Dietz, T. Economic Growth Does Not Reduce the Ecological Intensity of Human Well-Being. Sustain. Sci. 2015, 10, 149-156. [CrossRef]

6. Jorgenson, A.; Clark, B. Societies Consuming Nature: A Panel Study of the Ecological Footprints of Nations, 1960-2003. Soc. Sci. Res. 2011, 40, 226-244. [CrossRef]

7. Rice, J. Ecological Unequal Exchange: International Trade and Uneven Utilization of Environmental Space in the World System. Soc. Forces 2007, 85, 1369-1392. [CrossRef]

8. Roberts, T.; Parks, B. A Climate of Injustice: Global Inequality, North-South Politics, and Climate Policy; MIT Press: Cambridge, MA, USA, 2007.

9. Bunker, S. Modes of Extraction, Unequal Exchange, and the Progressive Underdevelopment of an Extreme Periphery: The Brazilian Amazon, 1600-1980. Am. J. Sociol. 1984, 89, 1017-1064. [CrossRef]

10. Burns, T.; Davis, B.; Kick, E. Position in the World-System and National Emissions of Greenhouse Gases. J. World Syst. Res. 1997, 3, 432-466. [CrossRef]

11. Grimes, P. The Horsemen and the Killing Fields. In Ecology and the World-System; Goldfrank, W., Goodman, D., Szasz, A., Eds.; Greenwood Press: Westport, CT, USA, 1999. 
12. Hornborg, A. Towards an Ecological Theory of Unequal Exchange: Articulating World System Theory and Ecological Economics. Ecol. Econ. 1998, 25, 127-136. [CrossRef]

13. Roberts, T.; Grimes, P. World-System Theory and the Environment: Toward a New Synthesis. In Sociological Theory and the Environment: Classical Foundations, Contemporary Insights; Dunlap, R., Buttel, F., Dickens, P., Gijswijt, A., Eds.; Rowman and Littlefield: Lanham, MD, USA, 2002.

14. Givens, J.; Clark, B.; Jorgenson, A. Strengthening the Ties between Environmental Sociology and the Sociology of Development. In Sociology of Development Handbook; Almeida, P., Brown, D., Cohn, S., Curran, S., Emigh, R., Hooks, G., Hung, H., Jorgenson, A., Lachmann, R., Lobao, L., et al, Eds.; University of California Press: Oakland, CA, USA, Forthcoming.

15. Jorgenson, A.; Clark, B. The Economy, Military, and Ecologically Unequal Relationships in Comparative Perspective: A Panel Study of the Ecological Footprints of Nations, 1975-2000. Soc. Problems 2009, 56, 621-646. [CrossRef]

16. Jorgenson, A.; Clark, B. Are the Economy and the Environment Decoupling? A Comparative International Study, 1960-2005. Am. J. Sociol. 2012, 118, 1-44. [CrossRef]

17. Chase-Dunn, C. Global Formation: Structures of the World-Economy; Rowman \& Littlefield: Lanham, MD, USA, 1998.

18. Hornborg, A., McNeill, J.R., Martinez-Alier, J., Eds.; Rethinking Environmental History: World-System History and Global Environmental Change; Alta Mira Press: Lanham, MD, USA, 2007.

19. Chase-Dunn, C.; Hall, T. Rise and Demise: Comparing World-Systems; Westview Press: Boulder, CO, USA, 1997.

20. Liu, J.; Dietz, T.; Carpenter, S.; Alberti, M.; Folke, C.; Moran, E.; Pell, A.; Deadman, P.; Kratz, T.; Lubchenco, J.; et al. Complexity of Coupled Human and Natural Systems. Science 2007, 317, 1513-1516. [CrossRef] [PubMed]

21. Liu, J.; Hull, V.; Batistella, M.; DeFries, R.; Dietz, T.; Fu, F.; Hertel, T.W.; Izaurralde, R.C.; Lambin, E.F.; Li, S.; et al. Framing Sustainability in a Telecoupled World. Ecol. Soc. 2003, 18, 26. [CrossRef]

22. Mol, A., Spaargaren, G., Sonnenfeld, D., Eds.; Ecological Modernisation: Three Decades of Policy, Practice and Theoretical Reflection. In The Ecological Modernisation Reader; Routledge: London, UK, 2009.

23. Grossman, G.; Krueger, A. Economic Growth and the Environment. Q. J. Econ. 1995, 110, 353-377. [CrossRef]

24. Mol, A. The Refinement of Production: Ecological Modernization Theory and the Chemical Industry; Van Arkel: Utrecht, The Netherlands, 1995.

25. Mol, A. Ecological Modernization and the Global Economy. Glob. Environ. Politics 2002, 2, 92-115. [CrossRef]

26. Mol, A. The Environmental Nation State in Decline. Environ. Politics 2016, 25, 48-68. [CrossRef]

27. Mol, A. Globalization and Environmental Reform; MIT Press: Cambridge, UK, 2001.

28. Inglehart, R. Culture Shift in Advanced Industrial Society; Princeton University Press: Princeton, NJ, USA, 1990.

29. Inglehart, R. Modernization and Postmodernization: Cultural, Economic, and Political Change in 43 Societies; Princeton University Press: Princeton, NJ, USA, 1997.

30. Inglehart, R.; Baker, W. Modernization, Cultural Change, and the Persistence of Traditional Values. Am. Sociol. Rev. 2000, 65, 19-51. [CrossRef]

31. Reijnders, L. The Factor X Debate: Setting Targets for Eco-Efficiency. J. Ind. Ecol. 1998, 2, 13-22. [CrossRef]

32. Schnaiberg, A. The Environment: From Surplus to Scarcity; Oxford University Press: New York, NY, USA, 1980.

33. Schnaiberg, A.; Gould, K. Environment and Society: The Enduring Conflict; St. Martin's Press: New York, NY, USA, 1994.

34. Gould, K.; Pellow, D.; Schnaiberg, A. Interrogating the Treadmill of Production: Everything You Wanted to Know about the Treadmill but Were Afraid to Ask. Organ. Environ. 2004, 17, 296-316. [CrossRef]

35. Gould, K.; Pellow, D.; Schnaiberg, A. The Treadmill of Production: Injustice and Unsustainability in the Global Economy; Paradigm Publishers: Boulder, CO, USA, 2008.

36. Jevons, W.S. Of the Economy of Fuel. Organ. Environ. 2001, 14, 99-104. [CrossRef]

37. York, R. Ecological Paradoxes: William Stanley Jevons and the Paperless Office. Hum. Ecol. Rev. 2006, 13, 143-147.

38. Foster, J.B.; Clark, B.; York, R. The Ecological Rift; Monthly Review Press: New York, NY, USA, 2010.

39. Pellow, D. Resisting Global Toxics: Transnational Movements for Environmental Justice; MIT Press: Cambridge, UK, 2007.

40. Dietz, T.; Rosa, E.; York, R. Driving the Human Ecological Footprint. Front. Ecol. Environ. 2007, 5, 13-18. [CrossRef] 
41. Jorgenson, A. Consumption and Environmental Degradation: A Cross-National Analysis of the Ecological Footprint. Soc. Problems 2003, 50, 374-394. [CrossRef]

42. Rosa, E.; York, R.; Dietz, T. Tracking the Anthropogenic Drivers of Ecological Impacts. Ambio 2004, 33, 509-512. [CrossRef] [PubMed]

43. York, R.; Rosa, E.; Dietz, T. Footprints on the Earth: The Environmental Consequences of Modernity. Am. Sociol. Rev. 2003, 68, 279-300. [CrossRef]

44. York, R.; Rosa, E.; Dietz, T. A Tale of Contrasting Trends: Three Measures of the Ecological Footprint in China, India, Japan, and the United States, 1961-2003. J. World Syst. Res. 2009, 15, 134-146. [CrossRef]

45. Jorgenson, A.; Birkholz, R. Assessing the Causes of Anthropogenic Methane Emissions in Comparative Perspective, 1990-2005. Ecol. Econ. 2010, 69, 2634-2643. [CrossRef]

46. Jorgenson, A.; Clark, B.; Giedraitis, V. The Temporal (in) Stability of the Carbon Dioxide Emissions/Economic Development Relationship in Central and Eastern European Nations. Soc. Nat. Resour. 2002, 25, 1182-1192. [CrossRef]

47. Knight, K.; Schor, J. Economic Growth and Climate Change: A Cross-National Analysis of Territorial and Consumption-Based Carbon Emissions in High-Income Countries. Sustainability 2014, 6, 3722-3731. [CrossRef]

48. Hornborg, A. Zero-Sum World: Challenges in Conceptualizing Environmental Load Displacement and Ecologically Unequal Exchange in the World-System. Int. J. Comp. Sociol. 2009, 50, 237-262. [CrossRef]

49. Jorgenson, A. Unequal Ecological Exchange and Environmental Degradation: A Theoretical Proposition and Cross-National Study of Deforestation, 1990-2000. Rural Sociol. 2006, 71, 685-712. [CrossRef]

50. Jorgenson, A.; Rice, J. Structural Dynamics of International Trade and Material Consumption: A Cross-National Study of the Ecological Footprint of Less-Developed Countries. J. World Syst. Res. 2005, 11, 57-77. [CrossRef]

51. Jorgenson, A.; Rice, J. The Sociology of Ecologically Unequal Exchange in Comparative Perspective. In Handbook of World-Systems Analysis: Theory and Research; Babones, S., Chase-Dunn, C., Eds.; Routledge Press: New York, NY, USA, 2012.

52. Bunker, S. Underdeveloping the Amazon: Extraction, Unequal Exchange, and the Failure of the Modern State; University of Illinois Press: Urbana, IL, USA, 1985.

53. Bunker, S.; Ciccantell, P. Globalization and the Race for Resources; Johns Hopkins University Press: Baltimore, MD, USA, 2005.

54. Hornborg, A. Global Ecology and Unequal Exchange: Fetishism in a Zero-Sum World; Routledge Press: New York, NY, USA, 2011.

55. Hornborg, A. The Power of the Machine: Global Inequalities of Economy, Technology, and Environment; Altamira Press: New York, NY, USA, 2001.

56. Rice, J. The Transnational Organization of Production and Uneven Environmental Degradation and Change in the World Economy. Int. J. Comp. Sociol. 2009, 50, 215-236. [CrossRef]

57. McMichael, P. Development and Social Change: A Global Perspective; Pine Forge Press: Thousand Oaks, CA, USA, 2012.

58. Jorgenson, A. Export Partner Dependence and Environmental Degradation, 1965-2000; Ph.D. Thesis, Department of Sociology, University of California, Riverside, CA, USA, 2004.

59. Shandra, J.; Schor, E.; London, B. World Polity, Unequal Exchange, and Organic Water Pollution: A Cross-National Analysis of Less Developed Nations. Hum. Ecol. Rev. 2009, 16, 51-64.

60. Rudel, T. Tropical Forests: Regional Paths of Destruction and Regeneration in the Late Twentieth Century; Columbia University Press: New York, NY, USA, 2005.

61. Jorgenson, A.; Dick, C.; Austin, K. The Vertical Flow of Primary Sector Exports and Deforestation in Less-Developed Countries: A Test of Ecologically Unequal Exchange Theory. Soc. Nat. Resour. 2010, 23, 888-897. [CrossRef]

62. Austin, K. The Hamburger Connection as Ecologically Unequal Exchange: A Cross-National Investigation of Beef Exports and Deforestation in Less-Developed Countries. Rural Sociol. 2010, 75, 270-299. [CrossRef]

63. Jorgenson, A. World-Economic Integration, Supply Depots, and Environmental Degradation: A Study of Ecologically Unequal Exchange, Foreign Investment Dependence, and Deforestation in Less-Developed Countries. Crit. Sociol. 2010, 36, 453-477. [CrossRef] 
64. Shandra, J.; Leckband, C.; McKinney, L.; London, B. Ecologically Unequal Exchange, World Polity, and Biodiversity Loss: A Cross-National Analysis of Threatened Mammals. Int. J. Comp. Sociol. 2009, 50, 285-310. [CrossRef]

65. Jorgenson, A. The Sociology of Unequal Exchange in Ecological Context: A Panel Study of Lower-Income Countries, 1975-2000. Sociol. Forum 2009, 24, 22-46. [CrossRef]

66. Jorgenson, A.; Austin, K.; Dick, C. Ecologically Unequal Exchange and the Resource Consumption/Environmental Degradation Paradox: A Panel Study of Less-Developed Countries, 1970-2000. Int. J. Comp. Sociol. 2009, 50, 263-284. [CrossRef]

67. Hooks, G.; Smith, C. The Treadmill of Destruction: National Sacrifice Areas and Native Americans. Am. Sociol. Rev. 2004, 69, 558-575. [CrossRef]

68. Hooks, G.; Smith, C. Treadmills of Production and Destruction: Threats to the Environment Posed by Militarism. Organ. Environ. 2005, 18, 19-37. [CrossRef]

69. Kentor, J. Capital and Coercion; Garland Publishing: New York, NY, USA, 2000.

70. Clark, B.; Bellamy, J. Ecological Imperialism and the Global Metabolic Rift: Unequal Exchange and the Guano/Nitrates Trade. Int. J. Comp. Sociol. 2009, 50, 311-334. [CrossRef]

71. Downey, L.; Bonds, E.; Clark, K. Natural Resource Extraction, Armed Violence, and Environmental Degradation. Organ. Environ. 2010, 23, 417-445. [PubMed]

72. Clark, B.; Jorgenson, A.; Kentor, J. Militarization and Energy Consumption: A Test of Treadmill of Destruction Theory in Comparative Perspective. Int. J. Sociol. 2010, 40, 23-43. [CrossRef]

73. Kentor, J.; Jorgenson, A.; Kick, E. The "New" Military and National Income Inequality: A Cross-National Analysis. Soc. Sci. Res. 2012, 41, 514-526. [CrossRef] [PubMed]

74. Rice, J. Material Consumption and Social Well-Being within the Periphery of the World Economy: An Ecological Analysis of Maternal Mortality. Soc. Sci. Res. 2008, 37, 1292-1309. [CrossRef] [PubMed]

75. Jorgenson, A. Carbon Dioxide Emissions in Central and Eastern European Nations, 1992-2005: A Test of Ecologically Unequal Exchange Theory. Hum. Ecol. Rev. 2010, 18, 105-114.

76. Jorgenson, A. The Sociology of Ecologically Unequal Exchange and Carbon Dioxide Emissions, 1960-2005. Soc. Sci. Res. 2010, 41, 242-252. [CrossRef] [PubMed]

77. York, R.; Rosa, E. Key Challenges to Ecological Modernization Theory: Institutional Efficacy, Case Study Evidence, Units of Analysis, and the Pace of Eco-efficiency. Organ. Environ. 2003, 16, 273-288. [CrossRef]

78. Bonds, E.; Downey, L. Green Technology and Ecologically Unequal Exchange: The Environmental and Social Consequences of Ecological Modernization in the World-System. J. World Syst. Res. 2012, 18, 167-186. [CrossRef]

79. Marquart-Pyatt, S.; Jorgenson, A.; Hamilton, L. Methodological Approaches for Sociological Research on Climate Change. In Climate Change and Society: Sociological Perspectives; Dunlap, R., Brulle, R., Eds.; Oxford University Press: Oxford, UK, 2015.

80. Chase-Dunn, C.; Jorgenson, A. Regions and Interaction Networks: An Institutional-Materialist Perspective. Int. J. Comp. Sociol. 2003, 44, 433-450. [CrossRef]

(C) 2016 by the author; licensee MDPI, Basel, Switzerland. This article is an open access article distributed under the terms and conditions of the Creative Commons by Attribution (CC-BY) license (http://creativecommons.org/licenses/by/4.0/). 